\title{
Getting the farm to the school: Increasing direct, local procurement in Yolo County schools
}

\author{
Data on in-season produce purchases and a collection of "forager" services support direct and \\ seasonal sales from farms to schools.
}

by Gail Feenstra, Shosha Capps, Kristy Lyn Levings, Elaine James, Mary Laurie, Mitchell Maniti and Emma Lee

arm to school programs bring food from regional
farms to school cafeterias, support school gardens
and promote food literacy. These programs have grown exponentially since the late 1990 s, with more than 42,500 schools participating nationwide in 2014. In California, 55\% of all school districts surveyed in 2013-2014 participated, representing 5,400 schools with 3 million children. Participating schools invested $\$ 167$ million in local food (as defined by their districts), with the average school district spending $15 \%$ of its food budget on local products (USDA FNS 2015).

The goal of the project described here was to build the capacity of local growers in and around Yolo County to sell more products directly to school food service buyers. Such sales can have several benefits for growers, including diversifying and expanding their markets as well as potentially receiving higher prices than wholesale distributors offer. For school food service buyers, purchasing direct from growers helps

\section{Abstract}

Since 2012, the UC Sustainable Agriculture Research and Education Program (SAREP) has worked with the Yolo County Department of Agriculture to support farm to school activities in Yolo County. In 2015, SAREP partnered with the Yolo County Department of Agriculture to deepen engagement with Yolo County growers and increase direct sales to Yolo County schools. SAREP tracked the volumes and prices of produce purchased by five school districts for the 2014-2015 baseline year and the 2015-2016 school year. Analysis was completed for three school districts for common produce items purchased, increases in in-season purchasing and direct grower versus distributor sales. For these districts, 17 produce items were in the top 10 for at least one of the districts; the five most common were apples, bananas, lettuce, oranges and strawberries, four of which are available locally for some or all of the school year. Districts purchased between $50 \%$ and $75 \%$ of their produce in season by the end of year two. All districts increased their purchases directly from growers. Findings suggest how services for growers and school food buyers can contribute to more local procurement.

Online: https://doi.org/10.3733/ca.2017a0024

\section{Workers prepare fresh} salads in the Davis Joint Unified School District central kitchen. Although direct sales can help growers expand their markets and in some cases receive higher prices, developing long-term purchasing relationships with school food service buyers has remained a challenge.

$-4$




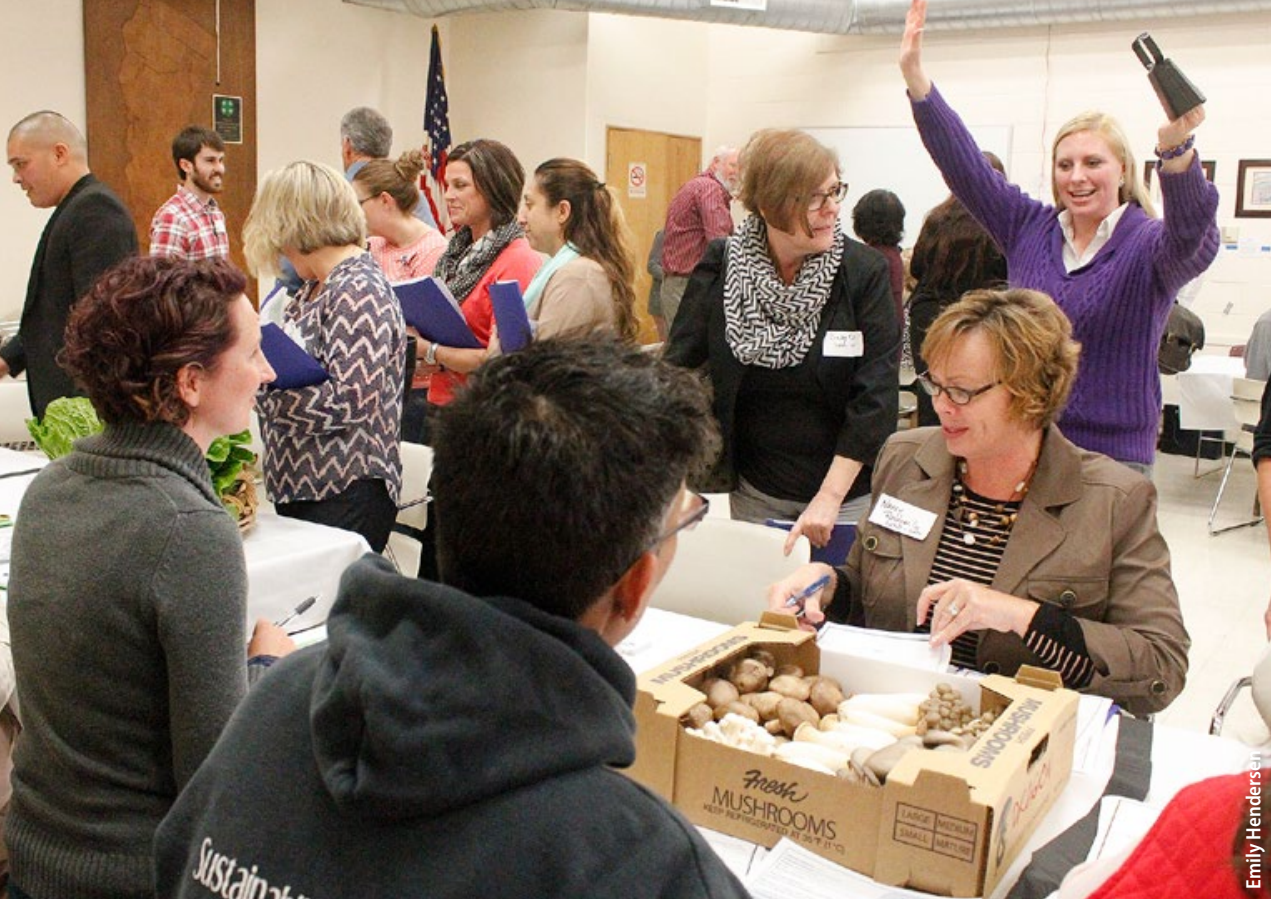

The Yolo County Department of Agriculture has hosted a series of Marketplace Exchanges, economic matchmaking events similar in structure to speed dating. At the meeting above, in Woodland in November 2014, growers were paired with buyers, such as school food service purchasers, for a series of 5-minute conversations.

to meet the typical goals of farm to school programs, including increasing documented spending in the local agricultural economy and enabling the identification and promotion of local growers on school menus, websites and newsletters or in the cafeteria.

The alternative way for growers to sell to institutional buyers is through a distributor. This is the way that most fresh produce is purchased for school cafeterias. Most produce distributors do not provide farmof-origin information (though some do). Distributors generally offer a selection of produce from many farms, near and far, at competitive prices, as well as greater convenience and more frequent deliveries compared to direct sales from farms.

For school food service buyers who want to support local growers through direct purchases, developing long-term, sustainable purchasing relationships has remained a challenge. Issues that are difficult for food service include drafting bidding language to give preference to regional produce, increased labor

\section{Forager services}

C hef and restauranteur Alice Waters popularized the use of the term "forager" in connection with direct sales from farms. At Waters' pioneering farm-to-table restaurant in Berkeley, Chez Panisse, the forager is the staff member responsible for sourcing ingredients from local farms. Today, some school districts and other institutional buyers have generalized the term to include a range of services such as helping to identify local farms from which to source products, facilitating sales through sharing farm produce availability listings, organizing farm tours for food service directors, and helping growers collect needed documents such as tax forms, proof of liability insurance, and food safety certifications. For the project described in this article, forager services were provided by the Yolo County Department of Agriculture. and adequate prices (Conner et al. 2011; Feenstra and Ohmart 2012; Izumi et al. 2009; Marshall et al. 2012).

In Yolo County, the county agricultural commissioner's office (Yolo County Department of Agriculture) and UC Agriculture and Natural Resources Sustainable Agriculture Research and Education Program (SAREP) have partnered to support farm to school activities since 2012, with a particular focus on increasing direct local produce purchasing by county school districts. Activities have included (1) professional development to help school food service staff incorporate more California specialty crops into school menus, (2) grower trainings on the logistics of selling to schools, (3) networking events to connect local growers and school food buyers, (4) evaluation of procurement practices and impacts, and (5) educational tours for policy- and decision-makers.

While this project focused on direct sales from farms to schools, we note that the goals of farm to school programs also may be achieved by sourcing produce from distributors that track farm-of-origin information. Some of the information collected for this project - in particular the data on seasonal produce - is also relevant to the procurement of local produce through a distributor.

\section{Project description}

In 2015, a new project was initiated with U.S. Department of Agriculture funding to focus on gathering school district purchasing data that would be meaningful to local growers (aggregated as pounds of produce rather than number of servings) to help them better assess what they might sell directly to schools and at what prices. The project also included individualized help for growers and school food service buyers in navigating logistics such as food safety certification, delivery options, seasonal pricing and learning about the farms and products through farm tours. This assistance can be valuable to some school food service buyers and growers, especially those just getting started in farmto-school purchasing. The project had the following goals: (1) analyze, over two school years, the produce purchasing patterns of five school districts in Yolo County (Davis Joint Unified School District, Esparto Unified School District, Woodland Joint Unified School District, Washington Unified School District and River Delta Unified School District), (2) translate crop purchasing data into yield and acreage terms that are more useful for growers, (3) provide training for growers to acquire GAP certification, and (4) provide farm to school "forager services" (see sidebar).

The project evaluation described here focuses on analyzing produce sales data over a 2 -year period. We did not formally evaluate other elements of the forager services such as the farm tours or GAP trainings. We hypothesized that all support services, including grower trainings and forager services, would influence 
purchasing decisions and therefore be reflected in changes in the data.

Produce purchasing patterns were analyzed for each district based on distributors' and growers' invoices for two school years: 2014-2015 (before the project started) and 2015-2016 (during the project). Funding was not available to analyze more years although it would have been interesting to see if longer term trends could be identified. Invoice data was summarized by pounds purchased, price paid, date (month and school year), supplier and whether the produce item was purchased in or out of its local season.

This data was used in three ways. First, it was analyzed to determine the most common produce purchases, the amount purchased in and out of season, and the average price paid per pound. Second, the number of pounds purchased was translated into yield and acreage (using data from the Yolo County Department of Agriculture) to assist growers in evaluating their capacity to meet school food service buyers' needs in the future and to make cropping decisions. Third, the data was analyzed to identify changes from pre-project purchasing (year 1) to intervention purchasing (year 2) in terms of in-season buying and purchases directly from growers. In-season purchases were defined following seasonality charts developed by the Center for Urban Education

About Sustainable Agriculture (CUESA 2016).

In the next section, we summarize trends in crops purchased, seasonal purchasing and direct purchasing for three of the school districts Davis, Woodland and Esparto - the districts for which data analysis was complete at the time of this writing. We do not include translation of this data into yields and acreage.

\section{Common crops}

Seventeen produce items, as shown in table 1, were in the top 10 (by dollars spent) for at least one of the three school districts in one of the two school years. Five - apples, bananas, lettuce, oranges and strawberries - show up in the top 10 at least four times. The top 10 produce items for each district account for the majority of all expenditures (62\% to $94 \%$ of total expenditures).

TABLE 1. The top 10 produce items purchased in each school district, by total dollar value

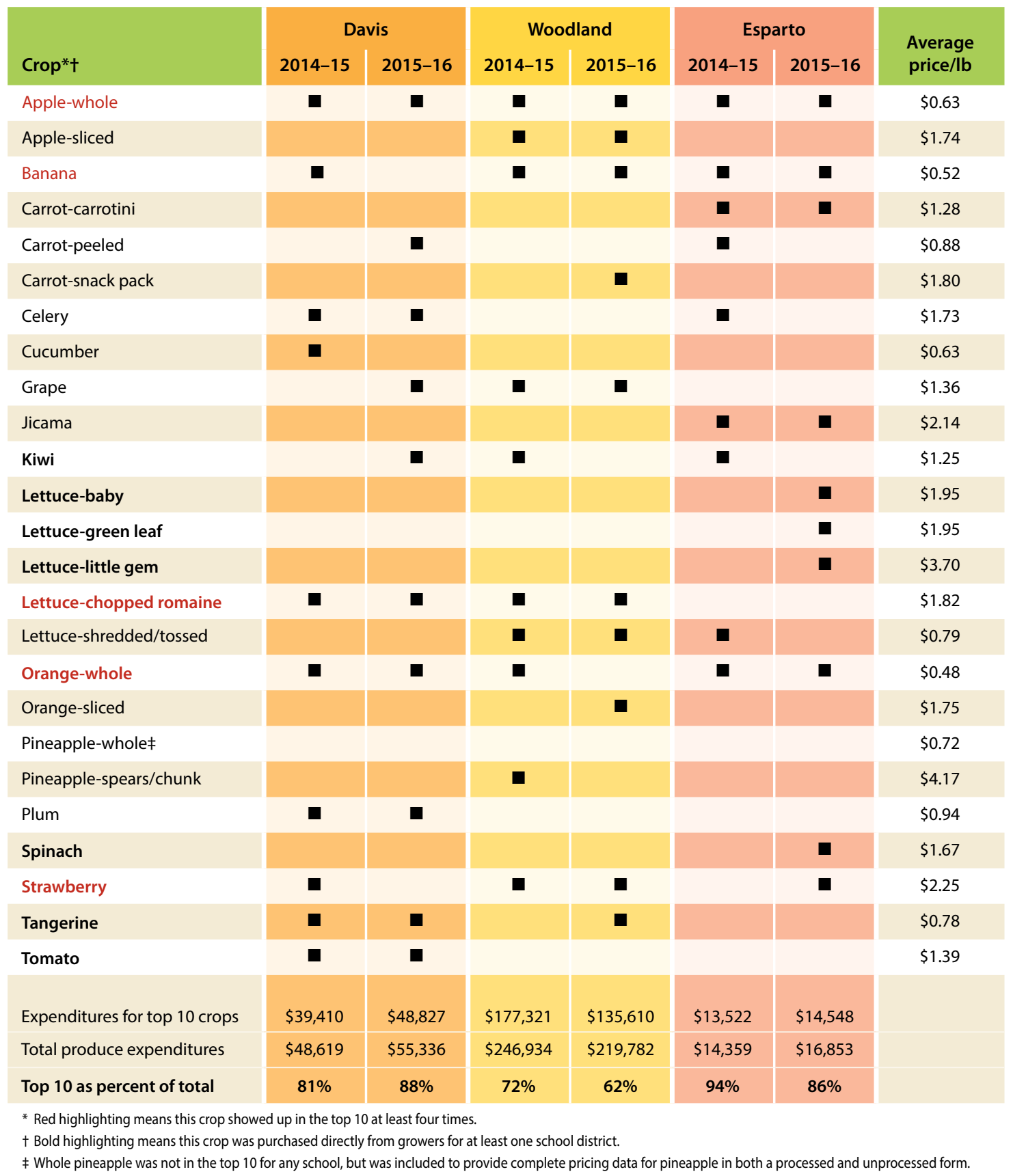




\section{Seasonal purchasing}

On an educational tour for elected officials and government staff, a food service director explains the contents of a graband-go salad for students.

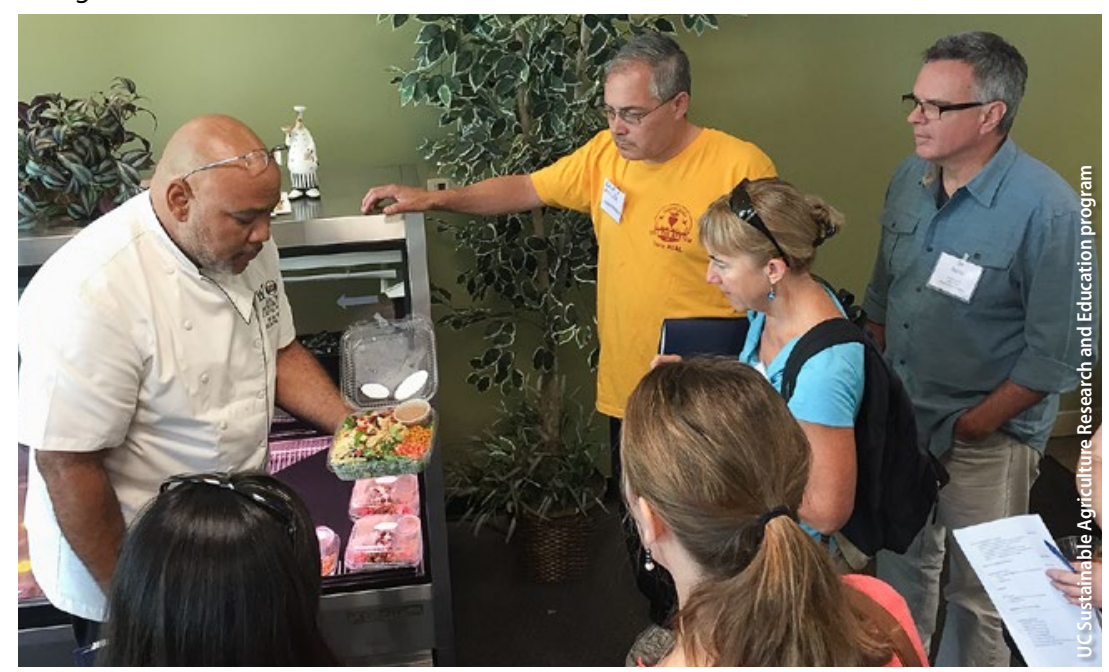

TABLE 2. Seasonality* of school district produce purchases

\begin{tabular}{|l|c|c|c|c|c|c|}
\hline & \multicolumn{2}{|c}{ Davis } & \multicolumn{2}{c|}{ Woodland } & \multicolumn{2}{c|}{ Esparto } \\
\hline $\begin{array}{l}\text { Amount } \\
\text { purchased }\end{array}$ & $\mathbf{2 0 1 4 - 1 5}$ & $\mathbf{2 0 1 5 - 1 6}$ & $\mathbf{2 0 1 4 - 1 5}$ & $\mathbf{2 0 1 5 - 1 6}$ & $\mathbf{2 0 1 4 - 1 5}$ & $\mathbf{2 0 1 5 - 1 6}$ \\
\hline $\begin{array}{l}\text { Total } \\
\text { purchases }\end{array}$ & $\$ 48,619$ & $\$ 55,336$ & $\$ 246,934$ & $\$ 219,782$ & $\$ 14,359$ & $\$ 16,853$ \\
\hline \begin{tabular}{l} 
Total in season \\
\hline Total out of
\end{tabular} & $\$ 37,862$ & $\$ 41,559$ & $\$ 119,527$ & $\$ 142,339$ & $\$ 6,563$ & $\$ 8,540$ \\
\hline $\begin{array}{l}\text { season } \\
\text { \% In season }\end{array}$ & $\mathbf{7 1 . 9 \%}$ & $75.1 \%$ & $48.4 \%$ & $64.7 \%$ & $45.7 \%$ & $50.7 \%$ \\
\hline
\end{tabular}

* Seasonality defined by CUESA seasonality charts (CUESA 2016).

TABLE 3. School district produce purchases from distributors and direct from farms

\begin{tabular}{|c|c|c|c|c|c|c|}
\hline \multirow[b]{2}{*}{ Amount purchased } & \multicolumn{2}{|c|}{ Davis } & \multicolumn{2}{|c|}{ Woodland } & \multicolumn{2}{|c|}{ Esparto } \\
\hline & 2014-15 & 2015-16 & 2014-15 & 2015-16 & 2014-15 & 2015-16 \\
\hline Total direct purchases & $\$ 0$ & $\$ 4,185$ & $\$ 4,053$ & $\$ 5,793$ & $\$ 747$ & $\$ 2,832$ \\
\hline $\begin{array}{l}\text { Total distributor } \\
\text { purchases }\end{array}$ & $\$ 48,619$ & $\$ 51,151$ & $\$ 242,881$ & $\$ 213,990$ & $\$ 13,612$ & $\$ 14,021$ \\
\hline$\%$ Direct & $0.0 \%$ & $7.6 \%$ & $1.6 \%$ & $2.6 \%$ & $5.2 \%$ & $16.8 \%$ \\
\hline $\begin{array}{l}\text { Items purchased direct } \\
\text { from farms }\end{array}$ & $\mathrm{n} / \mathrm{a}$ & $\begin{array}{c}\text { Cherry tomato } \\
\text { Kiwi } \\
\text { Lettuce } \\
\text { Onion } \\
\text { Watermelon }\end{array}$ & $\begin{array}{c}\text { Cabbage } \\
\text { Cucumber } \\
\text { Eggplant } \\
\text { Lettuce } \\
\text { Melon } \\
\text { Onion } \\
\text { Bell pepper } \\
\text { Tomato } \\
\text { Turnip } \\
\text { Watermelon }\end{array}$ & $\begin{array}{c}\text { Cabbage } \\
\text { Carrot } \\
\text { Lettuce } \\
\text { Mandarin } \\
\text { Persimmon } \\
\text { Tomato }\end{array}$ & $\begin{array}{c}\text { Asparagus } \\
\text { Lettuce } \\
\text { Orange }\end{array}$ & $\begin{array}{c}\text { Carrot } \\
\text { Cauliflower } \\
\text { Lettuce } \\
\text { Onion } \\
\text { Orange } \\
\text { Potato } \\
\text { Spinach } \\
\text { Strawberry } \\
\text { Tangerine }\end{array}$ \\
\hline
\end{tabular}

each district. In Davis, about $75 \%$ of all produce was purchased in season in both years. The percentage of produce purchased in season decreased slightly from $78 \%$ to $75 \%$ in the second year (2015-16). Inspection of the data shows this may partially be due to much larger purchases of whole apples and tangerines out of season in 2015-16. Woodland's purchases show a substantial increase in the percentage of produce purchased in season (from $48 \%$ to $65 \%$ ), mostly due to a very large decrease in the purchase of pineapple spears (which are always considered out of season in Northern California) in 2015-2016. Esparto increased its percentage of in-season purchasing from about $46 \%$ to $51 \%$. This is partially due to large increases in local products purchased in season in the second year (oranges, strawberries, lettuce, spinach, carrots).

\section{Direct purchasing}

Table 3 shows that all school districts increased the percentage of purchases directly from growers, although the increase was small for Woodland. Since Woodland was the biggest of the three districts, even $2.6 \%$ of total purchases amounted to $\$ 5,793$, the largest dollar amount spent with local growers in all three districts. The types of crops purchased directly from local growers for at least two school districts included lettuce, onions, watermelons, carrots and tangerines.

\section{Opportunities for direct sales}

Yolo County schools purchase many of the same crops. Five crops are in the top 10 for at least two districts (apples, bananas, oranges, strawberries and romaine lettuce). With the exception of bananas, all of these items can be sourced locally. If local growers are interested in exploring sales with schools, these popular produce items could be the focus of future planning. Three (lettuce, oranges and strawberries) were already being purchased locally during the preproject or project phases (see table 1).

Yolo County school districts purchase between half and threequarters of their produce in season, in part due to long regional growing seasons for many commonly purchased crops. However, it is possible to increase that percentage further by intentionally buying more products in season and replacing items that cannot be 
